This item was submitted to Loughborough's Research Repository by the author.

Items in Figshare are protected by copyright, with all rights reserved, unless otherwise indicated.

\title{
Building and maintaining strategic agility: An agenda and framework for executive IT leaders
}

\section{PLEASE CITE THE PUBLISHED VERSION}

https://doi.org/10.1177/0008125618790245

\section{PUBLISHER}

SAGE Publications (C) The Regents of the University of California

\section{VERSION}

AM (Accepted Manuscript)

\section{PUBLISHER STATEMENT}

This work is made available according to the conditions of the Creative Commons Attribution-NonCommercialNoDerivatives 4.0 International (CC BY-NC-ND 4.0) licence. Full details of this licence are available at: https://creativecommons.org/licenses/by-nc-nd/4.0/

\section{LICENCE}

CC BY-NC-ND 4.0

\section{REPOSITORY RECORD}

Morton, Josh, Patrick Stacey, and Matthias Mohn. 2018. "Building and Maintaining Strategic Agility: An Agenda and Framework for Executive IT Leaders". Loughborough University. https://hdl.handle.net/2134/32934. 


\section{Introduction}

This paper builds on the growing body of research concerning strategic agility ${ }^{1}$. While existing literature produces insights for organizations to achieve strategic agility, the role that key individuals play in the strategic agility process is underresearched. For example, organizations are advised to generate three high-level capabilities in order to achieve strategic agility: strategic sensitivity, resource fluidity and leadership unity ${ }^{2}$. Respective examples of these organizational capabilities include allowing collaborative strategic ideation such as by fostering open strategic conversations, dissociating strategy from structure to ensure resources are deployed rapidly, and mutual dependency to avoid political stalemates and personal insecurities at the top in strategy-making ${ }^{3}$. From past research, we 'know' what the essential strategic agility capabilities are, but what is not known nor documented is how to put these into practice; what do agile strategists ' $d o^{\prime}$ ? ${ }^{4}$. This is the focus of our paper - an in-depth investigation of the practices of agile strategists. Out of this investigation we derive a framework highlighting the practices of executive IT-leaders in building and maintaining strategic agility. We employ this move within the capabilities outlined above ${ }^{5}$ where there is a distinct lack of data in the form of case studies that document and analyze the micro, socio-political activities of agile strategy leaders. Yet more specifically, we lack an understanding of the agile strategy practices of top-level IT-leaders who are becoming ever more involved in strategic decision-making ${ }^{6}$. This IT-leadership focus is on account of the increasingly documented potential of IT to affect strategic agility ${ }^{7}$. It has been acknowledged that the topic would benefit from an understanding of how strategic agility is developed in distinct contexts ${ }^{8}$, such as executive IT-leadership. Specific insights such as these 
are also needed to help operationalize and guide a deeper understanding of the strategic agility concept ${ }^{9}$.

To respond to the above identified gaps in the literature, our paper poses the following research question: What are the practices of executive IT-leaders in building and maintaining strategic agility in organizations?

The research question also contains the notions of building and maintaining strategic agility; this is because it is deemed crucial in the literature that organizational leaders do not just enable a one-time transformation and realization of strategic agility, but weave strategic agility into the fabric of their organizations ${ }^{10}$. With the motivation for our research and a research question outlined, the contribution of our paper is twofold, and is structured accordingly:

Firstly, we demonstrate through a critical literature review that strategic agility research has been focussed at the organizational-level, to the detriment of understanding specific intricacies of strategic agility, i.e. how it is put into practice. We respond by providing empirical evidence of the strategic agility practices of executive IT-leaders from 18 (multi) national companies. Our research began as a consultancy project with a leading global consultancy firm, which snowballed into a more extensive research endeavour and involved organizations from the public and private sectors, and from several industries, including: communications and technology (IBM, Microsoft, XING AG), consultancy (Deloitte), consumer goods (Breitling, Colgate-Palmolive), defence (UK Ministry of Defence), entertainment (RTL Group), financial services (United Bank for Africa), and hospitality (Vienna Tourist Board). Secondly, we identify 'sets' of executive IT-leadership practices and

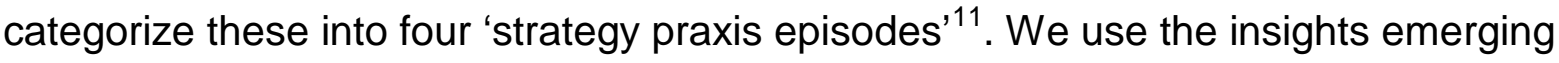


from the analysis of the collected data to explicate advice for executive IT-leaders to build and maintain strategic agility; this comprises an agenda and framework.

Currently there is a lack of such an agenda and framework that communicates and conceptualizes how the building and maintaining strategic agility is achieved in practice $^{12}$

\section{Critical Literature Review}

In this paper, strategic agility is "the practice of continuously adjusting and adapting strategic direction in core business in a flow of strategy praxis over time, as a function of strategic ambitions and changing circumstances" ${ }^{13}$. Although no agreed upon definition of strategic agility exists, there are three widely recognized capabilities of strategic agility which organizations must strive to build and maintain over time, namely: strategic sensitivity, resource fluidity, and leadership unity ${ }^{14}$. Whilst building strategic agility is an ongoing challenge for firms (Table 1), so is maintaining strategic agility once achieved (Table 2$)^{15}$.

\section{Insert Table 1 around here \\ Insert Table 2 around here}

Consequently, being able to build and maintain strategic agility has become a reallife, hard-to-resolve contradiction for organizations and their executive leaders. Building strategic agility may help companies gain momentum toward ambitious objectives. Paradoxically, however, difficulty in maintaining a fast and flexible strategic outlook may lead a company to develop inertia or be wrong-footed when technological disruptions occur, market circumstances change, or unexpected competitors appear ${ }^{16}$. As organizations seek to be strategically agile, the building and maintaining of strategic agility has become a conundrum for CEOs, and other 
top-level management involved in strategy-making ${ }^{17}$. This includes those leaders tasked with the management of organizational IT, and IT teams.

There has been an ever-increasing appreciation regarding the pivotal role of IT and IT-leaders ${ }^{18}$. This is particularly true through recognition of their centrality in strategy formulation and implementation ${ }^{19}$, and in impacting firm performance and competitive advantage ${ }^{20}$. By the late 1980's and early 1990's, contemporary technologies were widely considered as fundamental core capabilities of firms ${ }^{21}$, and IT-leaders were gaining prominence in top management teams for their knowledge and influence on strategy-making ${ }^{22}$. Porter and Millar $^{23}$ made the important distinction that the strategic significance of IT must be perceived more broadly than hardware, to encompass information and those executives who manage IT. Porter and Millar emphasized that these executives are leaders for the potential strategic implications of IT, such as on the rules of competition and advantage, and everyday operations. We define these practitioners broadly in this study as 'executive ITleaders'. This emphasizes that our focus is on top-level IT-leaders; those principally responsible for aligning digital strategy with business strategy through existing, internal technologies, and new customer facing technologies ${ }^{24}$. As a wide-ranging leadership constellation ${ }^{25}$, this incorporates roles such as the CIO, CTO, IT Director, Senior IT Manager and Vice-President of IT. Past research has explored these leaders through focus on strategic information management ${ }^{26}$, digital literacy ${ }^{27}$, alignment ${ }^{28}$, and the ever-changing evolution of their role as key organizational strategists ${ }^{29}$.

An established discourse exists on strategic agility within mainstream IT literatures. However, the focus to date has been on infrastructural issues, to the detriment of our understanding of human-social issues, particularly relating to the intricacies of 
everyday strategy and leadership ${ }^{30}$. Therefore, this has a similar deficiency to more mainstream strategic agility research in that it omits to study the micro practices of those enacting agile strategies. Moreover, in this literature stream, the enabling potential for strategies and organizational capabilities have been marginally dealt with when it comes to IT and strategic agility. For example, Luftman, Lewis and Oldach have conceptualized management processes for IT and business transformation in their strategic alignment framework, emphasizing how the strategic application of IT, and alignment of strategies, can transform organizations ${ }^{31}$. They also illuminate how IT infrastructure can be leveraged in order to facilitate a dynamic adaption of businesses to fast changing environments, whilst examining the requirements for organizational agility and connected IT infrastructures. Others have looked at the need for IT infrastructure to be more adaptive in line with the agile needs of organizations, especially through coupling contemporary web services with IT architectures ${ }^{32}$. Further, research has detected that IT infrastructure capabilities significantly relate to strategic agility, complemented by examination of how IT personnel capabilities determine such IT infrastructure capabilities, which in turn influence strategic agility ${ }^{33}$. As part of the evolving strategic significance of IT and its relation to strategic agility, the role of executive IT-leaders aiding organizations in both building and maintaining is therefore an important consideration.

In particular, executive IT-leaders have a prevalent role in light of the rapid pace of digital innovation ${ }^{34}$, which presents a conundrum of new opportunities and challenges $^{35}$. Existing studies indicate that in this digital revolution, executive ITleaders are having increasing input into strategic matters ${ }^{36}$. A series of IBM reports stress that the days of top-level IT-leaders being responsible solely for the delivery of reliable IT to businesses are firmly in the past ${ }^{37}$. Instead, contemporary IT-leaders 
will increasingly take broader roles in driving business transformation through innovating for competitive advantage, and helping nurture a unified top management team through being key strategic partners to the CEO and wider organization ${ }^{38}$. Mikko Kosonen emphasized this when reflecting on experiencing "the challenges of strategic agility for years" during his multi-faceted role as the $\mathrm{ClO}$ and lead strategist in a turbulent tenure at Nokia ${ }^{39}$. Through Kosonen's reign, Nokia built strategic agility as it transitioned through divergent stages of strategic sensitivity, resource fluidity and leadership unity ${ }^{40}$. Nokia failed to maintain these capabilities in the years after Kosonen's departure, however, and spiralled into eventual crisis. The organization struggled to maintain continued collaboration between departments, and stripped leaders of autonomy causing dis-unity and low morale. This led to a lack of foresight to emerging IT related opportunities and environmental changes, allowing competitors- notably Apple, Samsung and Google- to take grip of the market and drive mobile devices into the 'smart era'. Once seen as a cornerstone example of strategic agility, the Nokia story is now representative of strategic paralysis, permitting 'toxic side-effects' and emphasizes the importance of why firms must not only build strategic agility, but also need to maintain it over time ${ }^{41}$.

The case organizations explored in this paper have demonstrated that they are strategically agile. They have not only built strategic agility but have also maintained it, with IT and IT-leaders having had a fundamental role in this. For example, the role of IT and IT-leaders in ensuring continued collaboration for leadership unity is of central importance. In the communications and technology industry, Microsoft have demonstrated strategic agility through their implementation of agile Scrum ${ }^{42}$ methodologies which help drive ongoing adoption of innovative, shared leadership practices, whilst XING AG have adopted leadership toolkits and workshops to aid 
continued transparency of decision-making amongst top managers in different departments. Deloitte, meanwhile, have been active in supporting mutual leadership and decision-making by developing processes supported by big data analytics, which streamline activities and build alignment to key strategic capabilities. Deloitte uses the various techniques in its 'agile playbook' not only internally, but also markets these to clients as part of its consultancy services ${ }^{43}$. These examples of leadership unity not only ensure mutual dependency, collaboration and effective decision-making, but also help leaders avoid political stalemates and management divergence.

Building and maintaining strategic sensitivity is also fundamental, and one impact IT and IT-leaders have had in this regard is through enablement of a switch from 'analogue' strategy processes towards digital forms of strategy-making, such as online workspaces and discussion forums ${ }^{44}$. Examples of this have been demonstrated in IBM's Strategy Jams ${ }^{45}$ and the Vienna Tourist Boards 'Strategy 2020' idea contests, through which continued discussion around key strategic issues with internal and external stakeholders ensured heightened alertness and collaboration around strategy. The UK Ministry of Defence's internal Defence Connect and Defence Share platforms have similarly enabled the sharing of knowledge and insights between all levels of staff and leadership to drive high quality strategic dialogue. These collaborative approaches in turn ensure that strategic myopia and inertia are avoided, whilst helping to alleviate a dominance mind-set amongst leaders.

In the management and distribution of resources, IT and IT-leaders have been pivotal in driving open business-models, helping to build resource fluidity through digitization of internal systems and resources to allow rapid redeployment for 
strategic goals. For example, the United Bank for Africa have responded to competition from agile and hitherto unregulated 'Fintech' firms by implementing Banking as a Service (BaaS) initiatives ${ }^{46}$. An example is their EmailMoni cloud banking service, a digital, API-driven platform which focuses resource deployment in digital banking divisions to widen reach to existing customers and help grow new customer bases. In the consumer goods industry Colgate Palmolive have become a leader in supply chain digitization, utilizing SAP Cloud for more accurate resource allocation and faster strategic decision-making, whilst Breitling have opened an online boutique that relies on real-time analytics to increase interaction with customers and retail partners regarding product lines and stock. These examples also demonstrate agility for greater forward vertical integration. In the entertainment industry, faced with competition from on-demand firm Netflix, RTL group have adopted a hybrid business model ${ }^{47}$ by balancing free, advertising-funded entertainment with their own on-demand services with premium paid content on $\mathrm{PC}$, smartphones, tablets and internet-enabled televisions. In relation to resource fluidity, IT-leaders have been central here in maintaining strategic agility through careful monitoring of disruptive innovations and the work of tech-intensive rivals. This is essential to enabling fast deployment of resources in working towards sustained competitive advantage, and this helps firms avoid resource imprisonment and ensures a degree of strategic freedom.

In exploring extant work, the potential of IT and the importance of executive ITleaders in strategic agility is recognized, but the focus on infrastructure and organizational-levels of analysis have neglected an individual-level focus on the role they play that this study seeks to address. Examples relevant to the cases in this paper, emphasize the use of IT in building and maintaining capabilities for strategic 
agility whilst also illuminating the centrality of IT-leaders in this area. Reflecting upon the literature, potential practical implications, and case examples, we relate back to the question at the opening of this article, with the aim to provide an understanding of how strategic agility is built and maintained through practices of executive ITleaders.

\section{An Individual-Level of Analysis for Exploring Strategic Agility}

Whilst established high-level capabilities for strategic agility offer a useful grounding for understanding central concepts in its building and maintaining ${ }^{48}$, as we demonstrated in introducing our case examples in the previous section, little attention has been paid to the everyday practices which are the foundation of these organizational capabilities $^{49}$. This organizational-level focus has been to the detriment of understanding intricacies of strategic agility, i.e. how it is put into practice. We examine the role of executive IT-leaders in strategic agility, by taking a practice perspective and justify how this analyzes their role and specific practices in helping organizations build and maintain strategic agility. In the context of this study, the high-level capabilities for strategic agility remain essential for shaping the context and meaning of practices demonstrated by executive IT-leaders. This considered, two demands were required from the theoretical lens in relation to the central aim of this research. First, as a guide for the collection of data to highlight executive ITleaders in relation to their everyday role in organizational efforts to be strategically agile. Second, to clearly conceptualize executive IT-leaders in relation to building and maintaining strategic agility, highlighting how their strategy-making practices evolve over time ${ }^{50}$ 
A practice-theoretical lens was therefore used. Practice theories have gained momentum in scholarly work to overcome social theory's dualism between individualism and societism ${ }^{51}$. Relevant to the lens for exploring strategic agility in this study is that practice theorists have sought alternative mechanisms to examine people and their actions embedded in specific contexts. They aim to respect the efforts of individual actors but also their workings in relation to the organizationallevel phenomena ${ }^{52}$, similar to scholarship which has sought to understand the 'micro-foundations' of organizational routines and capabilities ${ }^{53}$. In strategy practice perspectives, however, frameworks seek to unpack the more intricate, everyday work of strategists. The term strategizing is frequently used to describe this 'doing of strategy' as a situated, socially accomplished activity ${ }^{54}$. Focus has expanded beyond top management to interrogate the role of other groups, such as middle managers ${ }^{55}$ and erstwhile non-strategists at different levels of organizations ${ }^{56}$, in strategizing processes. Focus has also centred on the strategy-making practices of those involved with organizational IT, to explore the technê and phronēsis of IT-leaders and consultants and understand more about what these strategists do ${ }^{57}$, alleviating their technical, leadership and managerial skills, and practical competence as strategists $^{58}$

A consensus exists in strategy practice literature regarding three core focal points: practitioners (the role and identity of the actors involved), practices (the methods of strategy-making), and praxis (how strategy work takes place) ${ }^{59}$. As is the motivation of this work, there is an inherent need to understand how people 'do' strategic agility and a focus on practitioners, practices and praxis offers a logical route towards this. Each of these three elements also comprises an analytic choice and way into the study of strategy. Although 'methodological bracketing' means that not all elements 
need to be combined in studies, it is useful to assume interconnectedness to provide understanding of strategy as an integrated whole ${ }^{60}$. Focussing on an individual-level of analysis in this study, these concepts are useful for examining how executive ITleaders as strategy practitioners perform sets of practices in building and maintaining strategic agility. Such sets can be conceptualized as episodes of strategy praxis, representing the doing of strategy by executive IT-leaders and the context within which they act and contribute to strategic agility. Whilst these episodes and practices are emerging, they are not strictly sequential, might overlap, and are based on nondeterministic interactions and may have varying degrees of occurrence and significance across time ${ }^{61}$. Notions of building and maintaining therefore constitute a number of practices unfolding in praxis episodes, and use of the three focal points as an established theoretical lens supports an individual-level of analysis as an appropriate starting point in this study.

\section{Consultancy Project Background and Methodology}

The methodological considerations for this study were partly pre-determined by our consultancy partner. The consultancy organization had an interest in gaining an understanding regarding the role of modern top-level IT-leaders in strategy. This was refined to explore what we have termed 'executive IT-leaders' and their role in strategic agility from both practitioner and academic perspectives.

\section{Data Collection}

We collected a mixture of primary and secondary data concerning the practices of executive IT-leaders in building and maintaining strategic agility (Table 3). Given the consultancy roots of the study, we had a brief to investigate how executive ITleaders were involved in strategy-making in a number of organizations. We did not 
take-for-granted that this was a valid line of enquiry however; we confirmed this by conducting background research using numerous secondary sources. We found abundant references to this phenomenon. For example, according to works by Deloitte, McKinsey, and IBM, executive IT-leaders increasingly take broader roles in driving business transformation through innovating for competitive advantage and acting as strategic partners to the CEO and wider organization ${ }^{62}$. Having confirmed that the line of enquiry was indeed valid through recognizing significant interest and concern expressed in the secondary sources, we also began to unveil examples which related to the strategic agility in relation to our own case organizations. We proceeded to collect in-depth primary data through semi-structured interviews in order to refine the phenomenon and expose intricacies regarding executive ITleaders and strategic agility. We also had privileged access to organizational platforms used for top-level strategic collaboration. These provided primary observation consistent with understanding technologies of strategizing and associated practices entangled in human and technology interaction ${ }^{63}$. This coincided with continued study of the academic literature on strategic agility, revealing a gap in knowledge concerning how strategic agility is operationalized and 'works' at the individual-level.

\section{Insert Table 3 around here}

Our interviews were conducted in 18 organizations of varying size and setting. This helped us understand practices in context. In total, 20 in-depth semi-structured interviews were completed. The 20 semi-structured interviews were conducted in line with work on empirical social research and study design, and participant information sheets were used to provide an overview of the strategic agility concept, whilst 'grand tour' questions were used to further interrogate the everyday practices and 
role of interviewees ${ }^{64}$. Our questions were targeted towards understanding what executive IT-leaders do in relation to their role and how they have contributed to their organizations being strategically agile.

In view of the paucity of research on the individual executives' role in strategic agility, and consistent with the theoretical lens adopted, we utilized an exploratory research design to study our highlighted research gap and guiding research question. This involved generating theory through induction, allowing for previously unexplored themes to be identified.

\section{Data Analysis}

Due to the lack of attention on strategic agility and executive IT-leaders, we adopted an inductive approach which does not pre-specify hypotheses to test but rather generates findings from the data. This analytic approach is consistent with existing practice-theoretical studies in strategy to explicate the key practitioners and practices unfolding in episodes of praxis ${ }^{65}$. This approach aligned with the aim of achieving rich understanding of individuals involved in everyday strategizing ${ }^{66}$. To ensure rigour in our work, and justify a qualitative approach, we integrated several considerations into our analysis. We used triangulation of qualitative sources to establish credibility, thick description to ensure transferability, multiple stages and researchers involved in coding to aid dependability, and outlined clear steps in the analysis to provide an empirical audit trail ${ }^{67}$.

The analytical procedure followed the data display and analysis method, combined with considerations from strategy practice studies ${ }^{68}$. This considered, the data display and analysis method translated into four steps for this research (Figure 1). 
The first step involved early-stage analysis and reduction of the interview and observation data by the authors, through referring to memos and by producing firstcycle codes from sentences and paragraphs in interview transcripts to capture richness. This helped reduce and provide commentary on what was happening in the data $^{69}$. The second step involved detailed coding and mapping the strategizing activity of participants through development of rich narratives ${ }^{70}$. This was supported using Nvivo software, with first-cycle codes refined through second-cycle coding to develop a greater sense of categorical and thematic organization of data relating to strategic agility. All authors were involved in this process and were in agreement with the coding outcomes. Categorization was based on the research focus and the guiding theoretical lens, emphasizing practitioners and practices in strategy praxis. Subsequent themes were developed inductively, and to ensure inter-coder dependability, the narratives and meanings of the themes were negotiated and then grouped into 13 specific practices. Although text is useful for demonstrating findings in research data, alone it can be cumbersome. Therefore, step three consisted of developing the narratives in relation to the substantiated findings with the aim of understanding the practices as distinct 'sets ${ }^{\text {'71 }}$. This involved grouping identified strategy practices into 'episodes' as finalized themes, and conceptualizing these in display form. This meant that the output could be summarized through displays emphasizing the focal points of the theoretical lens, whilst providing explicit implications by way of an agenda and framework for executive IT-leaders ${ }^{72}$. Step four was fundamental to grouping the previous steps and drawing conclusions. Discussing findings in relation to extant theory and practical implications is central here, as is discussing the themes identified relevant to notions of building and 
maintaining strategic agility. This helped to refine displays, ensuring clarity and applicability for executive IT-leaders in line with the emerging findings ${ }^{73}$.

\section{Executive IT-Leaders' Practices for Building and Maintaining}

\section{Strategic Agility}

The results of our study demonstrate that building and maintaining strategic agility constitute a number of practices by executive IT-leaders. This analysis demands attention around four core themes, positioned here as praxis episodes for strategic agility: (i) strengthen strategic influence, (ii) explore internal and external organizational domains, (iii) effectively communicate and collaborate, and (iv) manage tensions within organizations.

These four praxis episodes are documented in the first column of Table 4; the second column contains the specific practices for each praxis episode, and the third column provides a description of these practices. Table 4 is the agenda that we set out to construct in this paper. In the following section, we discuss the four praxis episodes in detail.

Insert Table 4 around here

\section{Strengthen strategic influence}

Referring to Table 4, a prominent finding was that executive IT-leaders express a need to be positioned and prepared to influence strategy, and this is important as a starting point to then influence strategic agility (Table 4, PE \#1). Although the importance of technological advancements has generally increased across all sectors and organizational domains, executive IT-leaders' strategic impact is still relevant to different industries. While IT-leaders in technology-driven organizations 
are more explicitly recognized as strategic influencers and are integrated in strategic dialogue and decision-making, in less information-intense industries a higher degree of positioning and preparing may be required. The findings indicate that executive ITleaders employ two main practices to reinforce their strategic impact on the boardlevel. In order to trigger strategic influence, executive IT-leaders utilize technologies strategically to provide competitive advantages and to drive value for the whole business. As a result of this, executive IT-leaders constantly improve their business knowledge in order to align technologies with strategic issues (Table 4, PO \#1). Such issues regarding strategic influence are a general organizational concern, due to existing governance structures within firms. In this regard, the findings here highlight that it is necessary for executive IT-leaders to report directly to the CEO as principle strategist, in addition to other relevant members of the top management team. Consequently, their strategic position has a higher chance of being acknowledged and their strategic ideas considered. To achieve increasing influence over time, executive IT-leaders also practice extensive self-marketing amongst the board, particularly through continued interaction and discourse with the CEO (Table 4, PO \#2).

\section{Explore internal and external organizational domains}

Referring to Table 4, the study reveals four sets of practices relating to executive ITleaders and a need to explore both internal and external organizational domains (PE \#2). This is also the most prominent strategy praxis episode.

Considering internal practices, it is evident that executive IT-leaders need to take up their role and become recognized as leaders that think strategically on the businesslevel and embrace themselves as catalysts for strategic change (Table 4, PO \#3). 
This requires impartiality and the development of an "entrepreneurial mind-set" in order to spot opportunities and embrace challenges of change. More specifically, approaching emerging technologies by structuring the technology portfolio and initiatives "like a venture capitalist" supports this process, as highlighted by three executives. The possibility of executive IT-leaders building strategic agility from an internal perspective is emphasized as being highly dependent on cultural conditions, and the cultural mind-set of the organization. In some cases, this is less prominent, but in others it is necessary to adapt to a culture that endorses testing and acknowledges failure as an important element of service development (Table 4, PO \#4). In this regard, the introduction of iterative development cycles that allow quick piloting and on-going improvements based on feedback and discussions are widely seen as being beneficial. One specific example is the "use of a minimum viable product approach, that enables everyone to contribute ideas", and that involves regular feedback cycles across departments and with customers.

Considering the external domain, executive IT-leaders are aware of their environment (Table 4, PO \#5). With the nature of their role, this includes being particularly conscious of emerging technologies and related trends through which value can be added to the business. Equally, executive IT-leaders are aware of those technologies or trends which could disrupt current processes or strategic directions. Hence, they "actively monitor the environment" in relation to arising opportunities and challenges to maintain strategic foresight. This implies a shift of focus from inbound operational and infrastructural issues, towards outbound market orientation and awareness for technological solutions for strategic opportunities. In a frequently used example, cloud technologies are highlighted as a means of 
outsourcing operational matters in order to enable executive IT-leaders to concentrate and justify a more strategic focus.

Also relevant to the external domain, is that executive IT-leaders increase their focus on interacting with customers directly (Table 4, PO \#6). The "value of data-driven customer insights based on sophisticated analytics solutions", for example, is mentioned. Additionally, opportunities to deploy 'profiles' in order to provide more suitable and better targeted products and services highlights a further valuable driver for executive IT-leaders to strategically adjust to changing demands, in addition to strategic movements of competitors. This demonstrates that executive IT-leaders strengthen both their individual and their departmental analytic capabilities. One interviewee, based at a global leader in the fast-moving consumer goods industry, highlights analytics and information as being an increasingly key strategic leverage in the role of executive IT-leaders, stating; "technology is fundamental, but I see an almost more important trend... which is what we call analytics. We have too much data and we don't know how to use it properly. We have to spend more time understanding, and more importantly, consolidating the information". Additionally, the strategic leverage of big data, and social platforms such as Facebook are also mentioned by multiple participants, as part of digital development strategies for recognizing and analyzing external domains.

\section{Effectively communicate and collaborate}

The next praxis episode identified relates to effective communication and collaboration (Table 4, PE \#3). This is emphasized as central for both building and maintaining strategic agility by enabling open forms of strategizing and ensuring others can relate and commit to strategies (Table 4, PO \#7). Interviewees highlight 
their use of internal social platforms which enable effective forms of open communication and collaboration throughout the organization, and help position executive IT-leaders at the centre of strategic ideation. IBM 'Strategy Jams', for example, are highlighted by an executive in the IBM CTO Europe team as being a means of executive IT-leaders opening strategic conversations; "you need to look at the values of the company and really see if there is sort of anything you need to resolve... and a strong belief that again things such as these corporate values are something employees have an opinion on and should be engaged in the process, which is effectively what we did [through Strategy Jams]". Additionally, this can be complemented through the facilitation of collaboration on the board-level, which in turn requires executive IT-leaders to adapt their communication with respect to their peers. In order to promote their initiatives, this requires careful adaptation and application of specific business language and to translate these explanations to terms that represent board-level discussions, such as cost, value and sustainability (Table 4, PO \#8).

Another benefit of effective communication and collaboration by executive ITleaders, between board members and departments, is breaking up silos within the organization (Table 4, PO \#9). Executive IT-leaders promote their initiatives across the whole business, to create an enthusiasm in order to drive strategic agility. They endeavour to ensure all stakeholders understand their objectives, and accordingly there is again a need to adjust language used (Table 4, PO \#8), adapting such language depending on their counterpart's seniority and expertise with certain topics. One interviewee suggests this can indirectly support executive IT-leaders' positioning as influencers at the board-level, in particular, as they will "provide their executive peers a better understanding of IT-driven visions and strategic initiatives". 
The need for effective communication and collaboration further implies regular exchanges of viewpoints as well as transparent and mutual exchanges of ideas in order to break up silo structures that hinder effective collaboration. This can be supported by the introduction of appropriate governance structures, or again can relate back to enabling open forms of strategizing and collaboration around strategic issues. This type of conversation across the organization means isolation of departments is avoided, silo-like structures are made less prominent, and stakeholders relate to proposed initiatives, helping to emphasize commitment. Subsequently, executive IT-leaders act as enablers for building and maintaining strategic agility, and help ensure that stakeholders at different levels are able to relate to particular strategic changes. One interviewee suggests that this is achieved through "linking the teams by employees who are more focused on business issues and IT issues". Those core stakeholders who have explicit, practical understanding of both these sides therefore help facilitate mutual exchange and understanding (Table 4, PO \#10).

\section{Manage tensions within organizations}

The final praxis episode identified was managing tensions within organizations (Table 4, PE \#4). In order to manage tensions within the board, the main practice identified for executive IT-leaders relates to reaching a mutual agreement among top-level management surrounding the strategic importance and potential impact of IT and related organizational processes (Table 4, PO \#11). Accordingly, communication and collaboration are significant again, but with a shift in focus to executive IT-leaders ensuring board members can understand their needs and proposals, and that tensions are managed at the board-level. Therefore, executive IT-leaders facilitate transparent and well-formulated interactions regarding their 
ideas. For achieving recognition of the strategic importance of IT, and subsequent shared commitment, executive IT-leaders promote their ideas effectively at board- or top management-level as a means of being recognized as competent and trusted strategic partners. This is important for creating a compelling mutual vision and strategy in order to hone everybody in on the same shared objectives, for benefit of the organization. This again reinforces that executive IT-leaders focus on appropriate business terminology while communicating with their peers on the board, a point more explicitly highlighted in considerations of communication and collaboration for building and maintaining strategic agility.

The practice of managing tensions within departments is also relevant (Table 4, PO \#12), and resembles the same practice emphasized at the board-level. Most pertinent here is the systematic creation of a common understanding of IT initiatives, as required to facilitate a shared commitment across departments comprising the organization in order to maintain continued strategic agility. This means providing a compelling vision and gaining mutual trust from different departments. The fundamentals again relate to aspects of communication and collaboration; however, executive IT-leaders also continually ensure that key stakeholders understand their proposals and initiatives. One IT Senior Manager stresses the significance of communication to overcome tensions, in that those involved more directly with business operations, and those more aligned with IT responsibilities, need to communicate in a way that "the other side can understand". Related to this, is that executive IT-leaders adapt an appropriate, participative leadership style to manage and ultimately avoid tensions amongst departments. Although guidance is required, authoritarian management is counterproductive in both building and maintaining strategic agility. Relevant to managing tensions across all levels of the organizations 
more generally, executive IT-leaders focus on acting as mentors and leading participation (Table 4, PO \#13). For example, as a regional CTO at Microsoft expressed; "You have to be able to mentor, coach and at the same time enforce. This is the role of the leader, being able to orchestrate and ensure to bring the diverse people to form together an effective team". This means explaining the sense of their commands meaningfully in relation to specific business- and corporate-level strategies.

\section{A Strategic Agility Framework for Executive IT-Leaders}

Following our analysis of the data, we now expand upon our agenda (Table 4) by offering a framework for executive IT-leaders. This framework joins these practitioners with praxis episodes and the associated practices for building and maintaining strategic agility (Figure 2). The bottom level of Figure 2 indicates executive IT-leaders as explored in our study (e.g. CIO, CTO, Vice-President of IT) as strategy practitioners. Here they are the critical connection between intraorganizational praxis, shown in the middle level of Figure 2, and the organizational and extra-organizational practices, shown in the top level of Figure 2, that they rely on in episodes of strategy practice relating to building and maintaining strategy agility. In the context of this study, the framework therefore details the outcomes of our work and uncovers an essential "set of management practices developed and honed over time" ${ }^{\prime 74}$. The framework in Figure 2 is intended as a guide which executive IT-leaders can use towards understanding their potential role in organizational strategic agility, and this discussion is written with the framework's theoretical and practical implications considered.

Insert Figure 2 around here 
The framework draws on practice-theoretical work in strategy to conceptualize executive IT-leaders as strategy practitioners and shows their role in strategizing; that is building and maintaining strategic agility through the interplay of distinct sets of practices in episodes of strategy praxis. The findings emphasize that executive ITleaders contribute, through their practices, to strategic agility in several ways. Notions of building and maintaining here are relevant to the continued application of these practices in different situations over time. Therefore, as illuminated previously, these episodes and associated practices are emerging, and are not sequential. Therefore, they might overlap, and are based on non-deterministic interactions and may have varying degrees of occurrence and significance across time and context. The two sets of practices relating to episodes of strengthening strategic influence, for example, demonstrate that executive IT-leaders are strategically sensitive and aid leadership unity by prioritizing the constant development of business knowledge, and align to business needs by using technologies strategically. In doing so, they practice self-marketing and enable channels to communicate regularly with the CEO on key strategic issues. This is with the aim of not only building strategic sensitivity and leadership unity, but to also maintain it by avoiding side-effects such as tunnel vision, inertia, and rigidity of expertise (Table 2).

Episodes of exploring internal and external organizational domains consists of four distinct sets of practices. The evolving role of executive IT-leaders is emphasized, explicating that they strive to be catalysts for strategic excellence and change. This is complemented by their encouragement of experimenting and testing new ideas and processes. Monitoring business environments and new technologies, whilst recognizing associated opportunities and challenges is also important, and complementary to this is a need to leverage data for insights and new analytical 
capabilities. These relate to multiple capabilities for strategic agility, particularly notions of building and maintaining resource fluidity and strategic sensitivity to avoid side-effects such as strategic myopia and management mediocrity, whilst ensuring strategic freedom is enabled (Table 2).

The four sets of practices concerning effective communication and collaboration suggest executive IT-leaders ensure others can relate and commit to, and be actively involved in, strategy-making. Facilitating 'open strategizing' is a key enabler of such action, and a way of ensuring strategic agility is built and maintained through ongoing dialogue. Also key is the ability to demonstrate knowledge through use of appropriate business language, and again empower open discussions where possible to break up silos and engage disparate groups. These practices are pertinent to building and maintaining strategic sensitivity, resource fluidity and leadership unity, particularly to ensure a dominance mind-set does not develop amongst leaders. Further, it ensures that competence gaps can be addressed, and knowledge and expertise shared rather than closely-guarded (Table 2).

Last, are three sets of practices relating to managing tensions within organizations. Executive IT-leaders again couple utilization of effective collaboration methods and reporting to the CEO, and are able to manage tensions with other top-level managers or board members through continued mutual communication. This continuity amongst top management is sustained through managing tensions within departments by having a participative and creative leadership style, and being a mentor to those across the organization. This unifies considerations of building and maintaining leadership unity with strategic sensitivity, ensuring leadership creativity in opposition to emotional apathy, management divergence and business system stagnation (Table 2). 


\section{Conclusion: Implications for Managers and Future Work}

In concluding, we discuss how the agenda (Table 4) and framework (Figure 2) address our original research question: What are the practices of executive ITleaders in building and maintaining strategic agility in organizations? We also outline the important implications of this study and recommend some pathways for future work.

Our analysis of the data collected from 18 (multi) national companies suggests that executive IT-leaders engage in practices that focus on self-development, improvement of business knowledge, and awareness of relevant environments. They are team players that facilitate exchange amongst the board, enabling communication and collaboration throughout the organization by using their knowledge of positioning technologies for strategic gain. Our findings suggest that executive IT-leaders consolidate and help nurture mutual enthusiasm for strategic issues; this is also essential in breaking up departmental silos ${ }^{75}$. Executive ITleaders also approach their role proactively to ensure capabilities central to building and maintaining strategic agility are sustained, and potential 'toxic side-effects' eluded.

Our study has important implications, both for organizations and managers seeking to build and maintain strategic agility, and scholars interested in this topic. These again stem from its main contribution; an understanding regarding the practices of executive IT-leaders in building and maintaining strategic agility, and the framework developed from an individual-level of analysis.

For executive IT-leaders, our agenda and framework form practical guides to help understand intricate insights to strategic agility as an organizational practice relevant 
to their work. To our knowledge, we are the first to provide detailed insights into the practices that are required to both build and maintain strategic agility from an executive IT-leader perspective. Through illuminating how executive IT-leaders strengthen their influence, explore organizational domains, effectively communicate and collaborate, and manage tensions to subsequently build and maintain strategic agility, we provide explicit, prescriptive advice to a broadly stated group of top-level managers in organizations. We envisage that this will help them in factors relating to being strategically agile. The findings here are relevant to executive IT-leaders across contexts, as was a core consideration of our research design, and act as a tool for executive IT-leaders to relate to and contrast with their own everyday practices. In terms of a contribution to theory, this empirical work has considered the cue that "insights into the varied nature of strategic agility are still lacking"76, and offers a new perspective to advance its understanding. By elaborating on established capabilities for strategic agility at the organizational-level, a significant gap is addressed by illuminating practices in episodes of strategizing for strategic agility, which have been largely ignored in the literature.

The article also offers a platform for future research. We call for researchers to continue to interrogate strategic agility at the individual-level, as a means of further understanding the intricate practices of the phenomenon, and to help guide practitioners in both building and maintaining this. It will also be useful for future work to extend upon this research to understand more about how episodes and different practices relate to the core capabilities for strategic agility as illuminated in established strategic agility frameworks ${ }^{77}$. Whilst we focused on executive IT-leader practices across several contexts, rather than sector or industry specific practices, this might offer a fruitful path to adapting and further expanding this work. We 
encourage researchers and practitioners alike to test the framework in different environments, and to extend the framework by identifying new praxis episodes and related practices which might be relevant to contexts both within and outside of the scope of this work. This means an individual-level of analysis might be used to examine whether our findings are also relevant to mid-level IT managers, non-ITexecutives, or to other organizational stakeholders and groups. Ultimately, future research might explore whether practitioners are able to adapt notions of praxis and practices as highlighted here, or whether they are able to uncover new practitioners, praxis, and practices altogether ${ }^{78}$.

The four key strategy praxis episodes, and associated sets of practices, highlight the strategic importance of IT-leaders, and contributes practical ways that these professionals can adjust and develop to be more aware about their strategic role in relation to building and maintaining strategic agility.

\section{Notes}

${ }^{1}$ A comprehensive synthesis of strategic agility research is provided in a 2014 special issue editorial, see: Y. Weber and S.Y. Tarba, "Strategic Agility: A State of the Art," California Management Review, 56/3 (Spring 2014): 5-12.

${ }^{2}$ Y. Doz and M. Kosonen, Fast Strategy (Harlow: Pearson Education, 2008).

${ }^{3}$ Doz and Kosonen (2008), op.cit.; Y. Doz and M. Kosonen, "The Dynamics of Strategic Agility: Nokia's Rollercoaster Experience," California Management Review, 50/3 (Spring 2008): 95-118; A. Franken and H. Thomsett, "When It Takes a Network: Creating Strategy and Agility through Wargaming," California Management Review, 55/3 (Spring 2013): 5-31.

${ }^{4}$ R. Whittington, "Completing the Practice Turn in Strategy Research," Organization Studies, 27/5 (May 2006): 613-34.

${ }^{5}$ Doz and Kosonen (2008), op.cit.; Doz and Kosonen (Spring 2008), op.cit.

${ }^{6}$ M. Carter, V. Grover and J.B. Thatcher, "The Emerging CIO Role of Business Technology Strategist," MIS Quarterly Executive, 10/1 (2011): 19-29; D.A. Marchand and J. Peppard, "Leadership Mindsets for IT Success," European Business Review, (April 2014). 
${ }^{7}$ See for example: Doz and Kosonen (2008), op.cit.; V. Sambamurthy, A. Bharadwaj and V. Grover, "Shaping Agility Through Digital Options: Reconceptualizing The Role of Information Technology in Contemporary Firms," MIS Quarterly, 27/2 (June 2003): 237-63; E. OwusuTucker and P. Stacey, "An Exploratory Study Assessing the Role Cloud Computing Has in Achieving Strategic Agility with the Banking Industry," Hawaii International Conference on Systems Sciences, Hawaii, USA.

${ }^{8}$ S.P.L. Fourné, J.J.P. Jansen and T.J.M. Mom, "Strategic Agility in MNEs: Managing Tensions to Capture Opportunities Across Emerging and Established Markets," California Management Review, 56/3 (Spring 2014): 13-38; Franken and Thomsett, op.cit.

${ }^{9}$ Weber and Tarba, op.cit.

${ }^{10}$ Doz and Kosonen (2008), op.cit.

${ }^{11}$ A. Tavakoli, D. Schlagwein and D. Schoder, "Open strategy: Literature review, re-analysis of cases and conceptualisation as a practice," Journal of Strategic Information Systems, 26/3 (September 2017):163-84; Whittington, op.cit.

${ }^{12}$ J. Peppard, R.D. Galliers and A. Thorogood, "Information systems strategy as practice: Micro strategy and strategizing for IS," Journal of Strategic Information Systems, 23/1 (March 2014): 1-10.

${ }^{13}$ Based on the definitions of strategic agility on the 'Fast Strategy' and strategic agility webpages maintained by Yves Doz, see: Y. Doz, "Our Research," strategicagility.com, 2014, < http://www.strategicagility.com/?Our_Research>

${ }^{14}$ Doz and Kosonen (Spring 2008), op.cit.; Weber and Tarba, op.cit.

${ }^{15}$ Notions of building and maintaining strategic agility in these tables are adapted from existing strategic agility literature, see: Doz and Kosonen (2008), op.cit.; Doz and Kosonen (Spring 2008), op.cit.; Fourné, Jansen and Mom, op.cit.

${ }^{16}$ D.N. Sull, "Why Good Companies Go Bad," Harvard Business Review, 77/4 (July 1999): 42-50; M.W. Lewis, C. Andriopoulos and W.K. Smith, "Paradoxical Leadership to Enable Strategic Agility," California Management Review, 56/3 (Spring 2014): 58-77; Doz and Kosonen (Spring 2008), op.cit.

${ }^{17}$ Doz and Kosonen (2008), op.cit.

${ }^{18}$ M.E. Porter and V.E. Millar, "How Information Gives You Competitive Advantage," Harvard Business Review, 63/4 (July 1985): 149-60.; Peppard, Galliers, and Thorogood, op.cit.

${ }^{19}$ T.C. Powell and A. Dent-Micallef, "Information technology as competitive advantage: The role of human, business, and technology resources," Strategic Management Journal, 18/5 (May 1997): 375-405.

${ }^{20}$ J.C. Henderson and N. Venkatraman, "Strategic alignment: Leveraging information technology for transforming organizations," IBM Systems Journal, 32/1 (January 1993): 47284. 
${ }^{21} \mathrm{H}$. Itami and T. Numagami, "Dynamic interaction between strategy and technology," Strategic Management Journal, 13/2 (December 1992): 119-35.

${ }^{22}$ B. Ives, "Editor's Comments: Transformed Information Systems Management," MIS Quarterly, 16/4 (December 1992): lix-Ixii.

${ }^{23}$ Porter and Millar, op.cit., p.149.

${ }^{24}$ Marchand and Peppard, op.cit.

${ }^{25}$ S. Ma and D. Seidl, "New CEOs and their Collaborators: Divergence and Convergence between the Strategic Leadership Constellation and the Top Management Team," Strategic Management Journal, 39/3 (October 2017): 606-638.

${ }^{26}$ Porter and Millar, op.cit.

${ }^{27}$ P. Gilster, Digital Literacy (New York, NY: John Wiley \& Sons, 1997).

${ }^{28}$ J. Luftman and T. Brier, "Achieving and Sustaining Business-IT Alignment," California Management Review, 42/1 (Fall 1999): 109-22.

${ }^{29}$ Marchand and Peppard, op.cit.

${ }^{30}$ L. Fink and S. Neumann, "Gaining Agility through IT Personnel Capabilities," Journal of the Association for Information Systems, 8/8 (August 2007): 440-62; Whittington, op.cit.; Peppard, Galliers and Thorogood, op.cit.

${ }^{31}$ J.N. Luftman, P.R. Lewis and S.H. Oldach, "Transforming the Enterprise: The Alignment of Business and Information Technology Strategies," IBM Systems Journal, 32/1 (January 1993): 198-221.

32 J.G. Mooney and D. Ganley, "Enabling Strategic Agility Through Agile Information Systems: The Roles of Loose Coupling and Web Service Oriented Architecture," In Agile Information Systems: Conceptualization, Construction and Management, 97-109, (Oxford: Butterworth-Heinemann, 2007).

${ }^{33}$ P. Weill, M. Subramani and M. Broadbent, "Building IT Infrastructure for Strategic Agility," MIT Sloan Management Review, 44/1 (October 2002); Sambamurthy, Bharadwaj and Grover (2003), op. cit.

34 J. Peppard, "A Tool for Balancing Your Company's Digital Investments," Harvard Business Review (October 2016).

35 J.M. Spitze and J.J. Lee, "The Renaissance ClO Project: The Invisible Factors of Extraordinary Success," California Management Review, 54/2 (Winter 2012): 72-91.

${ }^{36}$ J. Peppard, "Unlocking the performance of the Chief Information Officer (ClO)," California Management Review, 52/4 (Summer 2010): 73-99; P. Arandjelovic, L. Bulin, and N. Khan, "Why CIOs Should Be Business-Strategy Partners," Mckinsey Quarterly, (February 2015).

${ }^{37}$ This is from a series of IBM reports produced in 2008, see: IBM, "The Evolving Role of the ClO," Report, 2008. 
${ }^{38}$ M. Harrysson, D. Schoder, and A. Tavakoli, "Strategy in the Digital Age: The Evolution of Social Technologies," Mckinsey Quarterly (June 2016); Peppard, op.cit.; IBM, op.cit.

${ }^{39}$ This is from the video interview with Yves Doz and Mikko Kosonen by INSEAD, and the summarized and published transcription of an interview with Kosonen and Doz by Ruth Young, see: INSEAD, "Interview with Doz and Kosonen," 2008; R. Young, "Interview with Mikko Kosonen and Yves Doz," Strategic Direction, 24/7 (July 2008): 30-32.

${ }^{40}$ Doz and Kosonen (2008), op.cit.

${ }^{41}$ Y. Doz and K. Wilson, Ringtone: Exploring the Rise and Fall of Nokia in Mobile Phones (Oxford: Oxford University Press, 2018); Q. Huy and T. Vuori, "Who Killed Nokia? Nokia Did," INSEAD Knowledge, Report, 2015; Doz and Kosonen (Spring 2008), op.cit.

${ }^{42}$ Scrum methodologies are an agile process which focus on leadership practices for collaboration and self-organizing, particularly in technology and software development industries.

${ }^{43}$ Examples of Deloitte's 'agile playbook' are their NIMBLE programs and their Agile Transformation Approach.

${ }^{44}$ J. Baptista, A.D. Wilson, R.D. Galliers and S. Bynghall, "Social Media and the Emergence of Reflexiveness as a New Capability for Open Strategy," Long Range Planning, 50/3 (June 2017): 322-36.

${ }^{45}$ Strategy or Innovation Jams are on-line collaborative events involving the discussion and exchange of strategic ideas around a specific topic or a set of topics, see: O.M. Bjelland and R.C. Wood, "An Inside View of IBM's 'Innovation Jam'," MIT Sloan Management Review, (October 2008); Tavakoli, Schlagwein, and Schoder, op.cit.

${ }^{46}$ Banking as a Service (BaaS) is a process for overall execution of financial services online, see: O. Denecker, S. Gulati, and M. Niederkorn, "The digital battle that banks must win," McKinsey Quarterly (August 2014); P. Dintrans, A. An and, M. Ponnuveetil, A. Acharya, and A. Chardukian, "How Banking as a Service Will Keep Banks Digitally Relevant and Growing," Report, 2016.

${ }^{47}$ For further examples of hybrid business models, see: A. Bonaccorsi, S. Giannangeli, and C. Rossi, "Entry Strategies Under Competing Standards: Hybrid Business Models in the Open Source Software Industry," Management Science, 52/7 (July 2006): 1085-98; C. Baden-Fuller and S. Haefliger, "Business Models and Technological Innovation," Long Range Planning, 46/6 (December 2013): 419-26.

${ }^{48}$ This refers again to the established high-level capabilities for strategic agility; strategic sensitivity, resource fluidity, and leadership unity, see: N.N. Brueller, A. Carmeli and I. Drori, "How Do Different Types of Mergers and Acquisitions Facilitate Strategic Agility?," California Management Review (Spring 2014): 39-57; Doz and Kosonen (2008) op.cit.; Doz and Kosonen (Spring 2008), op.cit.

${ }^{49}$ One exception to this is the work of Doz and Kosonen which attempted to examine leadership practices for embedding strategic agility in the context of business model renewal, see: Y. Doz, and M. Kosonen, "Embedding Strategic Agility: A Leadership Agenda for Accelerating Business Model Renewal," Long Range Planning, 43/2-3 (April 2010): 37082. 
${ }^{50}$ A. Langley, "Strategies for Theorizing from Process Data," The Academy of Management Review, 24/4 (October 1999): 691-710.

${ }^{51}$ T.R. Schatzki, K.K. Cetina, and E. Von Savigny, The Practice Turn in Contemporary Theory (Routledge: London and New York, 2001); Whittington, op.cit.

${ }^{52}$ R. Chia and R. Holt, "Strategy as Practical Coping: A Heideggerian Perspective," Organization Studies, 27/5 (May 2006): 635-55.

${ }^{53}$ D.J. Teece, "Explicating Dynamic Capabilities: The Nature and Microfoundations of (Sustainable) Enterprise Performance," Strategic Management Journal, 28/13 (August 2007): 1319-1350; C.E. Helfat and M.A. Peteraf, "Managerial Cognitive Capabilities and the Microfoundations of Dynamic Capabilities," Strategic Management Journal, 36/6 (April 2014): 831-50.

${ }^{54}$ P. Jarzabkowski, J. Balogun, and D. Seidl, "Strategizing: The challenges of a practice perspective," Human Relations, 60/1 (January 2007): 5-27; E. Vaara and R. Whittington, "Strategy-as-Practice: Taking Social Practices Seriously," The Academy of Management Annals, 6/1 (March 2012): 285-336.

${ }^{55}$ S. Mantere, "Role Expectations and Middle Manager Strategic Agency," Journal of Management Studies, 45/2 (November 2007): 294-316.

${ }^{56}$ H. Chesbrough and M.M. Appleyard, "Open Innovation and Strategy," California Management Review, 50/1 (Fall 2007): 57-76; D. Stieger, K. Matzler, S. Chatterjee and F. Ladstaetter-Fussenegger, "Democratizing Strategy: How Crowdsourcing Can Be Used for Strategy Dialogues," California Management Review. 54/4 (Summer 2012): 44-68.

${ }^{57}$ Peppard, Galliers and Thorogood, op.cit.

${ }^{58}$ Spitze and Lee, op.cit.

${ }^{59}$ Vaara and Whittington, op.cit.

${ }^{60}$ A. Giddens, Central Problems in Social Theory (Berkeley: University of California Press, 1979); Whittington, op.cit.

${ }^{61}$ J. Hendry and D. Seidl, "The Structure and Significance of Strategic Episodes: Social Systems Theory and the Routine Practices of Strategic Change," Journal of Management Studies, 40/1 (January 2003): 175-96; Tavakoli, Schlagwein, and Schoder, op.cit.

${ }^{62}$ P. Laurent and J. Nielsen, "Technology Infrastructure at a glance: Strategy, Improvements and Challenges," Report, 2015; Harrysson, Schoder, and Tavakoli, op.cit.; IBM, op.cit.

${ }^{63}$ W.J. Orlikowski, "Sociomaterial Practices: Exploring Technology at Work," Organization Studies, 28/9 (September 2007): 1435-48; Tavakoli, Schlagwein, and Schoder, op.cit.

${ }^{64}$ J.P. Spradley, The Ethnographic Interview (Boston: Wadsworth Publishing, 1979).

${ }^{65}$ This is consistent with other practice-theoretical studies, see: P. Jarzabkowski and J.

Balogun, "The Practice and Process of Delivering Integration through Strategic Planning," 
Journal of Management Studies, $46 / 9$ (July 2009): 1255-88; Balogun, op.cit.; Jarzabkowski, Balogun, and Seidl, op.cit.

${ }^{66}$ M.B. Miles and M.A. Huberman, Qualitative Data Analysis: An Expanded Sourcebook (Thousand Oaks, CA: Sage, 1994); Whittington, op.cit.

${ }^{67}$ E.G. Guba and Y.S. Lincoln, Naturalistic Inquiry (Thousand Oaks, CA: Sage, 1985).

${ }^{68}$ Data display and analysis consists of three central activities: data reduction, data display, and conclusion drawing and verification and is a suited to an inductive approach to analyzing qualitative data. In practice-theoretical work, it has also been recommended to add a fourth activity -comparison with theory- helping align emerging findings and conclusions with current theories, see: J. Balogun, "Inductive Theorising: Using 'Organization' Theory," $6^{\text {th }}$ Strategy as Practice Annual Workshop, London, UK, 2004; Jarzabkowski, Balogun, and Seidl, op.cit; Miles and Huberman, op.cit.

${ }^{69}$ D. Silverman, Doing qualitative research: A practical handbook (Thousand Oaks, CA: Sage, 2000).

${ }^{70}$ Langley, op.cit.

${ }^{71}$ Whittington, op.cit.

${ }^{72}$ This was also particularly important given the strong focus on providing advice for managers from our study and devised framework.

${ }^{73}$ Miles and Huberman, op.cit.

${ }^{74}$ Doz and Kosonen (2008), op.cit., p.371.

${ }^{75}$ P. Stacey and J. Nandhakumar, "Opening up to agile games development," Communications of the ACM, 51/12 (December 2008): 143-46.

${ }^{76}$ Fourné, Jansen and Mom, op.cit.

${ }^{77}$ The established strategic agility framework referred to in this work was devised by Yvez Doz and Mikko Kosonen, see: Doz and Kosonen (2008), op.cit.; Doz and Kosonen (Spring 2008), op.cit.

${ }^{78}$ Whittington, op.cit. 


\begin{tabular}{|c|c|c|}
\hline $\begin{array}{l}\text { High-Level } \\
\text { Strategic } \\
\text { Agility } \\
\text { Capability }\end{array}$ & $\begin{array}{c}\text { Description of } \\
\text { Capability }\end{array}$ & Key Steps for Building Strategic Agility \\
\hline $\begin{array}{l}\text { Strategic } \\
\text { Sensitivity }\end{array}$ & $\begin{array}{l}\text { The sharpness of } \\
\text { perception and the } \\
\text { intensity of } \\
\text { awareness and } \\
\text { attention }\end{array}$ & $\begin{array}{ll}\text { - } & \text { Allowing an 'open strategy' process } \\
\text { through fostering open strategic } \\
\text { conversations } \\
\text { - } \\
\text { Heightened strategic alertness and } \\
\text { enabling business development } \\
\text { experiments to take place } \\
\text { - } \quad \text { High quality internal dialogue and means of } \\
\text { ensuring internal connectivity and } \\
\text { collaboration occur }\end{array}$ \\
\hline Resource Fluidity & $\begin{array}{l}\text { Internal capabilities } \\
\text { to reconfigure } \\
\text { activity systems } \\
\text { and redeploy } \\
\text { resources rapidly }\end{array}$ & $\begin{array}{ll} & \text { Dissociating strategy from structure to } \\
\text { ensure resources are deployed rapidly } \\
\text { - } & \text { Mobilizing people to enable effective } \\
\text { delivery of strategic goals } \\
\text { - } \quad \text { Modular processes for resource allocation, } \\
\text { including incentives for continued } \\
\text { collaboration processes }\end{array}$ \\
\hline Leadership Unity & $\begin{array}{l}\text { The ability of } \\
\text { senior teams to } \\
\text { make bold, 'fast' } \\
\text { decisions, without } \\
\text { being caught up } \\
\text { in 'win-lose' politics } \\
\text { at the top }\end{array}$ & 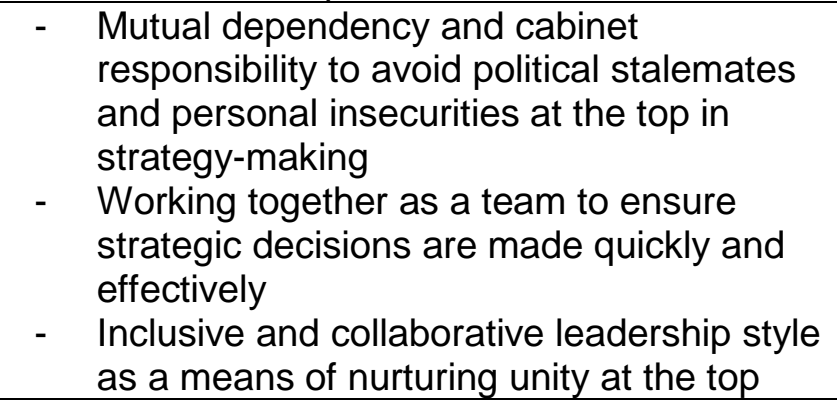 \\
\hline
\end{tabular}

Table 1: Key Capabilities and Steps for Building Strategic Agility 


\begin{tabular}{|c|c|c|}
\hline $\begin{array}{l}\text { High-Level } \\
\text { Strategic } \\
\text { Agility } \\
\text { Capability }\end{array}$ & Driver and Consequence & $\begin{array}{l}\text { Potential } \\
\text { 'Toxic Side- } \\
\text { Effects' }\end{array}$ \\
\hline $\begin{array}{l}\text { Strategic } \\
\text { Sensitivity }\end{array}$ & $\begin{array}{l}\text { - In having a clear vision for the future, organizations } \\
\text { risk consideration of everything out of this core } \\
\text { vision as irrelevant } \\
\text { - } \quad \text { Tight focus on continuous improvement can lead to } \\
\text { a short-term internal orientation } \\
\text { - Striving to be the leader in everything the } \\
\text { organization does risks reluctance to openly } \\
\text { collaborate and experiment } \\
\text { - Too much focus on maximally leveraging core } \\
\text { business can lead to framing everything in the light } \\
\text { of this core }\end{array}$ & $\begin{array}{l}\text { Tunnel vision } \\
\text { Strategic } \\
\text { myopia } \\
\text { Dominance } \\
\text { mind-set } \\
\text { Active inertia }\end{array}$ \\
\hline $\begin{array}{l}\text { Resource } \\
\text { Fluidity }\end{array}$ & $\begin{array}{l}\text { - Strong business units with sufficient autonomy as } \\
\text { they grow might lead to core business managers } \\
\text { sitting on their resources } \\
\text { - Highly efficient business systems and processes } \\
\text { may lead to increasingly differentiated and } \\
\text { specialized ('fit for purpose') activities } \\
\text { - } \quad \text { Having deep collaborative relationships with key } \\
\text { customers, partners, stakeholders may mean } \\
\text { customers and partners/stakeholders 'lock in' } \\
\text { leading to decreased strategic freedom } \\
\text { - Wanting a culture of learning by doing and building } \\
\text { on experience might mean forgiven and hidden } \\
\text { shortcoming emerge }\end{array}$ & $\begin{array}{l}\text { Resource } \\
\text { imprisonment } \\
\text { Business } \\
\text { system } \\
\text { stagnation } \\
\text { Restricted } \\
\text { strategic } \\
\text { freedom } \\
\text { Management } \\
\text { mediocrity and } \\
\text { competence } \\
\text { gaps }\end{array}$ \\
\hline $\begin{array}{l}\text { Leadership } \\
\text { Unity }\end{array}$ & $\begin{array}{l}\text { - Desire to have clear charters for organizational unit } \\
\text { may lead to declining intensity of dialogue and } \\
\text { decreasing need for collective commitments } \\
\text { - Having strong leaders with a proven track-record } \\
\text { may lead to inflated egos, overly bold } \\
\text { commitments, and implicit pecking order } \\
\text { - } \quad \text { Having individuals with strong specialized } \\
\text { expertise may lead to decisions elevating to the top } \\
\text { team and decisions being made by the 'same' } \\
\text { experts } \\
\text { - Having experienced long-tenures, leaders may } \\
\text { look to tired and same old ideas with future } \\
\text { opportunities looking less exciting and fruitful than } \\
\text { past experiences }\end{array}$ & $\begin{array}{l}\text { Management } \\
\text { divergence } \\
\text { Self- } \\
\text { importance of } \\
\text { management } \\
\text { Rigidity of } \\
\text { expertise } \\
\text { Emotional } \\
\text { apathy }\end{array}$ \\
\hline
\end{tabular}

Table 2: Key Capabilities and Reasons Organizations Fail to Maintain Strategic Agility 


\begin{tabular}{|l|l|}
\hline \multicolumn{1}{|c|}{ Type of Data Source } & \multicolumn{1}{c|}{ Data Source } \\
\hline Primary & $\bullet 20$ semi-structured interviews \\
& $\bullet \quad$ Observation of 4 online collaborative platforms \\
\hline Secondary & $\bullet \quad 118$ company annual reports \\
& $\bullet \quad 200$ social media profiles of executive IT-leaders \\
& $\bullet \quad 61$ industry and consultancy reports \\
\hline
\end{tabular}

Table 3: Overview of Data Sources 
Stage 1: Reduce data through initial coding
Stage 2: Identify practices through detailed coding
Stage 3: Group practices into episodes of strategy praxis
Stage 4: Conclusion drawing and comparison with theory

Example extracts
from interviews:
Example interview
extract: "You generally
have to lay claim, that's
the first step. They
have to generate this
awareness at the CEO
and the other directors
from the departments
as a service providerin
the company. Self-
Marketing is the first
step. To set yourself on
your feet and say, 'Hey,
l'm here, I have an
idea'."
"........."

\section{Example}

practices and

descriptions:

Practice:

Reporting

Description:

Report to the

CEO and

practice self-

marketing

Practice:

Consolidating

Description:

Break up silos

across the

organization.

\section{Example}

praxis

episodes:

Practices:

Developing

"..........."

Episodes of strengthening

strategic

influence

Practices:

Opening

".

Episodes of

effectively

communicating

and

collaborating
Building and maintaining strategic agility:

Developing to build heightened strategic awareness.

Maintain Developing to avoid 'tunnel vision'
Opening to build open strategic dialogues.

Maintain Opening to avoid dominance mind-set and lack of experimentation

Figure 1: Data Structure and Stages of Data Analysis 


\begin{tabular}{|c|c|c|}
\hline $\begin{array}{l}\text { Praxis Episodes } \\
\text { for Building and } \\
\text { Maintaining } \\
\text { Strategic Agility } \\
\text { (PE) }\end{array}$ & $\begin{array}{l}\text { Strategic Agility } \\
\text { Practices and } \\
\text { Occurrence } \\
\text { (PO) }\end{array}$ & $\begin{array}{l}\text { Description of the } \\
\text { Practices }\end{array}$ \\
\hline \multirow[t]{2}{*}{$\begin{array}{l}\# 1 . \text { Strengthen } \\
\text { strategic influence }\end{array}$} & $\begin{array}{l}\text { \#1. Developing } \\
\text { Knowledge (30) }\end{array}$ & $\begin{array}{l}\text { Develop and improve business } \\
\text { knowledge and use technologies } \\
\text { strategically }\end{array}$ \\
\hline & \#2. Reporting (14) & $\begin{array}{l}\text { Report to the CEO and practice } \\
\text { self-marketing }\end{array}$ \\
\hline \multirow{4}{*}{$\begin{array}{l}\text { \#2. Explore internal } \\
\text { and external } \\
\text { organizational } \\
\text { domains }\end{array}$} & \#3. Evolving Role (20) & $\begin{array}{l}\text { Embrace being a strategist and } \\
\text { catalyst for change. Act } \\
\text { 'entrepreneurial' }\end{array}$ \\
\hline & $\begin{array}{l}\text { \#4. Adapting Culture } \\
\text { (16) }\end{array}$ & $\begin{array}{l}\text { Adapt organizational culture } \\
\text { through encouraging testing, trial } \\
\text { and error. Implement iterative } \\
\text { processes and experimentation }\end{array}$ \\
\hline & \#5. Monitoring (24) & $\begin{array}{l}\text { Have awareness of surroundings } \\
\text { by monitoring technology and } \\
\text { business environments. Recognize } \\
\text { opportunities and challenges }\end{array}$ \\
\hline & $\begin{array}{l}\text { \#6. Leveraging Data } \\
\text { (13) }\end{array}$ & $\begin{array}{l}\text { Leverage data for new insights and } \\
\text { take a customer focus. Develop } \\
\text { analytic capabilities }\end{array}$ \\
\hline \multirow[t]{4}{*}{$\begin{array}{l}\text { \#3. Effectively } \\
\text { communicate and } \\
\text { collaborate }\end{array}$} & $\begin{array}{l}\text { \#7. Opening Strategy } \\
\text { (9) }\end{array}$ & $\begin{array}{l}\text { Enable ways of including others in } \\
\text { discussion and collaboration. Use } \\
\text { open forms of strategizing }\end{array}$ \\
\hline & $\begin{array}{l}\text { \#8. Applying } \\
\text { Language ( } 7)\end{array}$ & $\begin{array}{l}\text { Use and apply appropriate } \\
\text { business language when } \\
\text { necessary }\end{array}$ \\
\hline & \#9. Consolidating (6) & $\begin{array}{l}\text { Break up silos across the } \\
\text { organization }\end{array}$ \\
\hline & $\begin{array}{l}\text { \#10. Fostering } \\
\text { Direction (23) }\end{array}$ & $\begin{array}{l}\text { Ensure others can relate to, and } \\
\text { commit to strategies }\end{array}$ \\
\hline \multirow[t]{3}{*}{$\begin{array}{l}\text { \#4. Manage tensions } \\
\text { within organizations }\end{array}$} & \#11. Balancing (12) & $\begin{array}{l}\text { Manage tensions with senior } \\
\text { managers and the board through } \\
\text { mutual communication }\end{array}$ \\
\hline & \#12. Leading (22) & $\begin{array}{l}\text { Manage tensions within } \\
\text { departments through creation of } \\
\text { vision and a participative } \\
\text { leadership style }\end{array}$ \\
\hline & \#13. Mentoring (8) & $\begin{array}{l}\text { Mentor and coach, and justify } \\
\text { commands meaningfully }\end{array}$ \\
\hline
\end{tabular}

Table 4: Agenda for Executive IT-Leaders to Build and Maintain Strategic Agility 


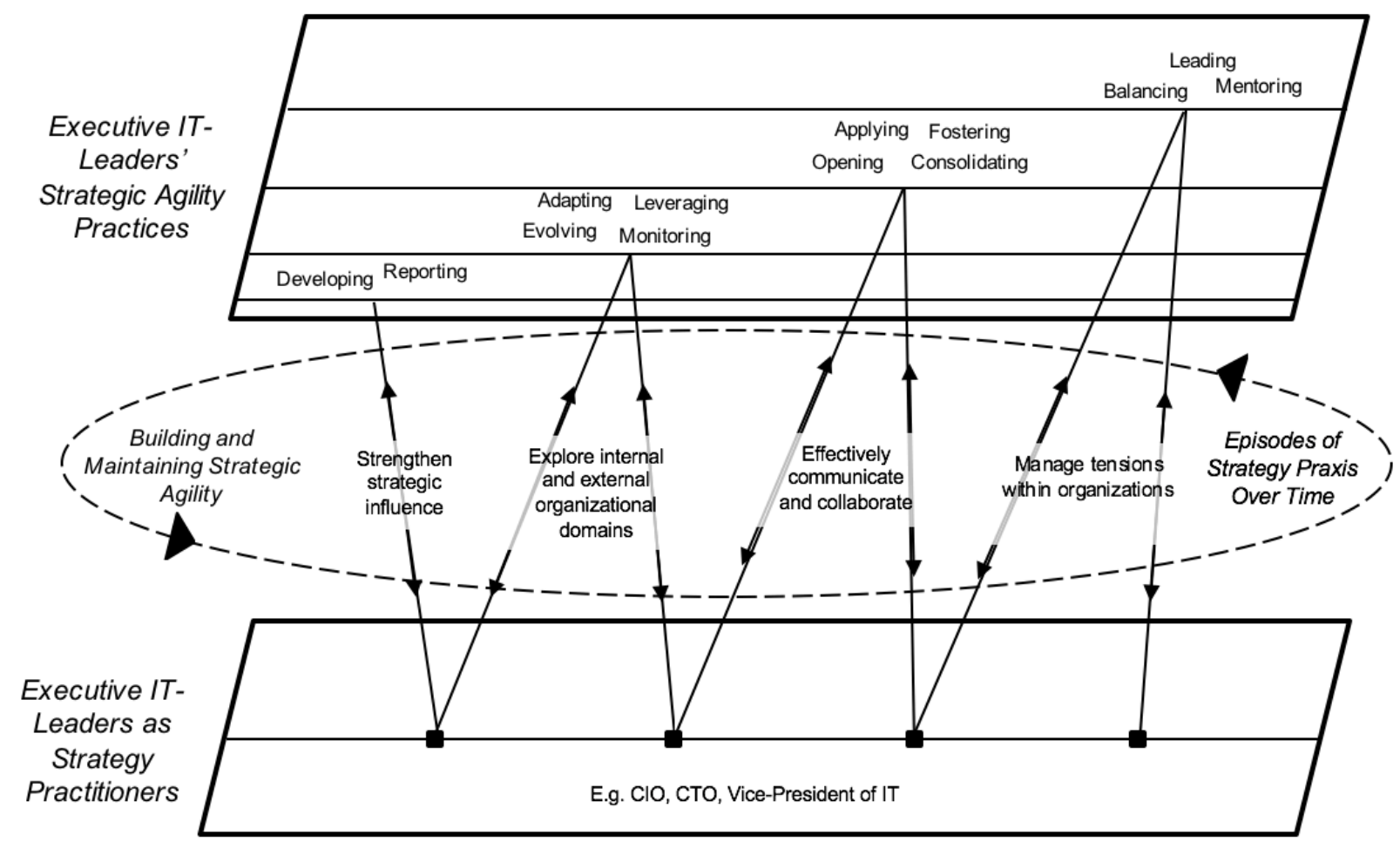

Figure 2: A Framework for Executive IT-Leaders to Build and Maintain Strategic Agility 